\title{
Total phenolic and lignin contents, phytochemical screening, antioxidant and fungal inhibition properties of the heartwood extractives of ten Congo Basin tree species
}

\author{
Steeve Mounguengui ${ }^{1}$ - Jean-Bosco Saha Tchinda ${ }^{2,3}$ - Maurice Kor Ndikontar ${ }^{2}$. \\ Stéphane Dumarçay ${ }^{3}$. Christiane Attéké ${ }^{6}$ Dominique Perrin ${ }^{3}$ Eric Gelhaye ${ }^{4,5}$. \\ Philippe Gérardin ${ }^{3}$
}

Received: 18 February 2015 / Accepted: 7 August 2015 /Published online: 8 September 2015

(C) INRA and Springer-Verlag France 2015

\begin{abstract}
- Key message Content and type of extractives vary considerably among woody species in the Congo Basin tropical forest. They influence the natural durability of wood with respect to fungal and insect degradation. Species containing higher amounts of extractives and Klason lignin
\end{abstract}

\section{Handling Editor: Jean-Michel Leban}

Contribution of the co-authors Steeve Mounguengui, Jean-Bosco Tchinda Saha, and Christiane Attéké: carrying out the experiments, interpreting the results, and writing the first draft of the paper

Stéphane Dumarçay, Dominique Perrin, and Eric Gelhaye: supervising experimental work and interpreting the results

Philippe Gérardin, Maurice Kor Ndikontar: co-designing and coordination of the PhD thesis of JB Saha Tchinda, supervision of work, interpreting the results, and final correction of the paper.

Philippe Gérardin

philippe.gerardin@univ-lorraine.fr

1 Institut de Recherche en Ecologie Tropicale (IRET), BP 13354, Libreville, Gabon

2 Laboratory of Macromolecular Chemistry, University of Yaounde 1, BP 812, Yaounde, Cameroon

3 Laboratoire d'Etudes et de Recherche sur le Matériau Bois (LERMAB), Faculté des Sciences et Technologies, Université de Lorraine, EA 4370 USC INRA, BP 70239, F-54506 Vandoeuvre lès Nancy, France

4 Faculté des Sciences et Technologies, Université de Lorraine, UMR 1136, Interaction Arbres Microorganismes (IAM), BP 70239, 54506 Vandoeuvre lès Nancy, France

5 INRA Centre de Nancy Lorraine, INRA, UMR 1136, Interaction Arbres Microorganismes (IAM), Route d'Amance, 54280 Champenoux, France

6 Unité de Recherche en Agronomie et Biologie, Université des Sciences et Techniques de Masuku, BP 901, Franceville, Gabon were generally less susceptible to fungal colonization. Phenolic extractives with large anti-fungal and high antioxidant activities were the main chemical family of compounds extracted from the tested species, which suggests a potential chemical valorization of these extractives.

- Context Several woody species from the Congo Basin are known for their natural durability, but the causes of this natural durability are not always fully elucidated. This is particularly the case for the resistance to white rotting fungi decay.

- Aims The chemical composition as well as the antioxidant activity of the heartwood extractives of several species were quantified and correlated to the ability of different fungi to colonize wood sawdusts in order to better understand their decay resistance.

- Methods The chemical screening of extracts was conducted using colorimetric methods. The quantity of lignin, extracts and total phenolic compounds, as well as antioxidant activities were determined. Extracted and unextracted heartwood sawdusts were exposed to two white rot fungi to assess the effect of extractives on their colonization.

- Results Extractives and lignin contents ranged from 2.7 to $16.0 \%$ and from 26.5 to $35.9 \%$, respectively. Antioxidant activity was directly connected to total phenolic contents. The phytochemical screening revealed the presence of different chemical groups in all extracts. Resistance to fungi was correlated to the amount of extractives and in most cases to the lignin content.

- Conclusion Phenolic compounds associated with antioxidant activities influenced the natural resistance of heartwood.

Keywords Antioxidant $\cdot$ Wood extractives $\cdot$ Phytochemical screening $\cdot$ Growth inhibition $\cdot$ White rots $\cdot$ Wood 


\section{Introduction}

The Congo Basin, with 227 million ha of forest area, contains the world's second largest tropical forest, after the Amazon basin. Forest sector activities currently contribute 3 to $9 \%$ of the gross domestic product in Central African nations (Cameroon, Equatorial Guinea, Gabon, the Central African Republic, the Republic of Congo, and the Democratic Republic of Congo) and more than $19 \%$ of employments. The Congo Basin is very rich in biodiversity with over 10,000 plant species, including over 20 common tree species commercially exploited (Comifac 2010). Trees of the Congo Basin are mainly constituted by angiosperms that can be differentiated by their structural elements. Various studies have shown that the chemical composition of hardwoods of temperate zones is different from those of tropical regions (Pettersen 1984; Kilic and Niemz 2012). Studies on hardwoods which are naturally durable from temperate zone are well documented (Aloui et al. 2004; Guilley et al. 2004; Kirker et al. 2013), but very little information exists on the natural durability of tree species from the equatorial tropical forest of Africa (CIRAD 2012; Nzokou et al. 2005; Antwi-Boasiako and Pitman 2009; Antwi-Boasiako et al. 2010) despite the tremendous foreign exchange earnings and the increasing potential for wealth creation obtainable from this sector.

The natural resistance of wood to fungal and/or insect decay is defined as the ability of wood to resist biological degradation and contribute to the natural durability of wood. In fact, only the heartwood of some species is durable; the sapwood of all tree species is relatively non-durable. Much controversy exists on the effect of density, lignin content, and hydrophobic properties on the natural durability of wood (Tuomela et al. 2000; Neya et al. 2004; Antwi-Boasiako and Pitman 2009; Oliveira et al. 2010; Skyba et al. 2013). Nevertheless, authors are unanimous on the role of extractives on the natural durability of wood. The amount of extractives varies greatly in woods (Antwi-Boasiako et al. 2010; Kilic and Niemz 2012; Ndukwe et al. 2012). Generally, heartwood extractives have some limited fungicidal properties. Moreover, in hardwood, these toxic compounds are usually phenolics such as tannins, flavonoids, and stilbenes (Schultz and Nicholas 2002; Oliveira et al. 2010; Nascimento et al. 2013). Some species have also non-phenolic extractives such as quinones and terpenoids. For example, the molecules responsible for the natural durability of Tectona grandis consist of toxic quinones, which have been shown to possess fungicidal properties (Niamké et al. 2011, 2012). It has also been noted that polyphenols can be used as antioxidant for food preservation to replace butylated hydroxyanisole (BHA) and butylated hydroxytoluene (BHT) (Saha et al. 2013). The toxicity of extractives has also been reported to be correlated to their antioxidant activity (Schultz and Nicholas 2002; Amusant et al. 2007).
Among the different organisms involved in tropical hardwood biodegradation, the most important and potent agents are fungi and termites (Onuorah 2000; Kokutse et al. 2006; Mburu et al. 2007; Antwi-Boasiako et al. 2010).

The objective of the present study was to understand the role of extractives on wood colonization by white rot fungi of the Congo Basin species. The identification of chemical families contained in extractives gives an idea about the molecules that may be involved in wood resistance to fungal colonization. The natural resistance of ten African heartwood species were determined according to the method described by Oliveira et al. (2010) using sawdust of Amazonian woods. The role of extractives on natural durability was evaluated by removing extractives in test sawdusts and visual evaluation of fungal growth of Pycnoporus sanguineus and Phanerochaete chrysosporium, and the results were compared to unextracted test sawdusts and the sawdust of poplar (positive control). Moreover, phytochemical screening and antioxidant properties of extractives were investigated in order to correlate the chemical properties of the latter and natural resistance of wood to fungal colonization.

\section{Materials and methods}

\subsection{Raw materials}

Samples of Bahia (Hallea ciliate (Aubrév. \& Pellegr.) J.F. Leroy), Bilinga (Nauclea diderrichii (De wild.) Merr), doussie (Afzelia bipidensis Harms), okan (Cylicodiscus gabunensis Harms), Okoume (Aucoumea klaineana Pierre), and Ozigo (Dacryodes buttneiri (Engl.) H.J.Lam) were collected from the Société Bordamur (Libreville, Gabon), and those of moabi (Baillonella toxisperma Pierre), movingui (Distemonanthus benthamianus Baill), padouk (Pterocarpus soyauxii Taub), and tali (Erythrophleum suaveolens (Guill. \& Perr.) Brenan) were from the Société Industrielle de Mbang (Yaoundé, Cameroon). Information on the occurrence, habitat and properties of the different tree species as well as their commercial and scientific names are provided in Table 1 . These species may have different names depending on the African countries. Heartwood samples of dimensions $30 \times 5 \times 5 \mathrm{~cm}$ were made in the longitudinal, radial, and tangential directions, respectively. All trees were between 60 and 70 years old and were collected from different piles of the two forest companies. All the samples were converted into wood meal using a cutter mill, air dried in the laboratory, and sieved. The fraction of the particle sizes between 0.2 and $0.4 \mathrm{~mm}$ was retained for extraction, while the fraction of particle sizes greater than $0.4 \mathrm{~mm}$ was used for fungi-growing inhibition tests. 
Table 1 Characteristic of the different wood species studied

\begin{tabular}{l} 
Wood species \\
\hline Hallea ciliate (Aubrév. \& Pellegr.) \\
J.-F. Leroy) Occurs: Congo Basin, \\
Nigeria Family: Rubiaceae \\
Commercial name: Bahia, Abura \\
Nauclea diderrichii (De wild.) Merr \\
Occurs: Congo Basin, Nigeria Family: \\
Rubiaceae Commercial name: Bilinga
\end{tabular}

Afzelia bipidensis Harms Occurs: Congo Basin, East of Africa Family: Caesalpiniaceae Commercial name: doussie

\section{Baillonella toxisperma Pierre Occurs: between Nigeria and Congo Basin Family: Sapotaceae Commercial name: moabi}

\author{
Distemonanthus benthamianus \\ Baill Occurs: Congo Basin, \\ Nigeria Family: Caesalpiniaceae \\ Commercial name: movingui \\ Cylicodiscus gabunensis Harms \\ Occurs: Congo Basin, Nigeria \\ Family: Mimosaceae Commercial \\ name: okan
}

\author{
Aucoumea klaineana Pierre \\ Occurs: Congo Basin Family: \\ Burséraceae Commercial name: \\ Okoume
}

\author{
Dacryodes buttneiri (Engl.) H.J.Lam \\ Occurs: Congo Basin, Uganda \\ Family: Burseraceae Commercial \\ name: Ozigo \\ Pterocarpus soyauxii Taub Occurs: \\ Congo Basin Family: Fabaceae \\ Commercial name: African padouk
}

Erythrophleum suaveolens (Guill. \& Perr.) Brenan Occurs: Congo Basin, Nigeria Family: Caesalpiniaceae Commercial name: tali
Characteristics and uses

References

Wood has very low durability to fungal attack according to standard NF EN $350-2$. Wood is used to make class furniture and interior joinery

Wood is very durable against fungi and termites according to standard NF EN $350-2$. Wood is used in heavy frames, hydraulic works, and interior joinery. The total phenolic compounds content in the methanol extracts as well as fungal inhibition were very low

Wood is considered very durable against wood-destroying fungi and termites according to standard NF EN 350-2. Wood is used in heavy frames, hydraulic works, interior joinery, bridge. The extractive wood contains high quantity of dihydrokaempferol, naringenin, and kaempferol.

Wood is very durable to fungi decay and termite attack according to standard NF EN 350-2 but is susceptible to lyctus attack. Trunk is used in building lumber. Wood contains relatively high amounts of extracts with acetone $(13.1 \%)$ but low total phenol contents and low antioxidant activity

Wood has an average natural durability to fungi decay, termites attack according to standard NF EN 350-2. Wood is used in exterior and interior joinery. Extractive of wood has higher antioxidant

Wood is very durable against fungi and termites according to standard NF EN $350-2$. Wood is used in heavy frames, hydraulic works, interior joinery, and bridge. The extract from wood showed the highest antioxidant activity compared at the $(+)$-catechin, which is known as a potent antioxidant

Wood is considered low durability against wood-destroying fungi and very sensible to termites according to standard NF EN $350-2$. Wood is used to make paneling, shuttering, and interior plywood. The extractive of wood contains many acidic compounds, $(+)$-catechin and the sterols

Wood is considered low durability against wood-destroying fungi and very sensible to termites according to standard NF EN 350-2. Wood is used to make paneling, shuttering, and current furniture

Has a natural resistance to fungi decay and termite attack according to standard NF EN 350-2. Its wood is used inexterior and interior joinery, framework, and for the manufacture of canoes. The extract from wood showed the highest antioxidant activity

Has a natural resistance to fungi decay and termite attack according to standard NF EN $350-2$. Wood is used for framework and making railway sleepers in Africa and Europe.
CIRAD 2012

CIRAD 2012 Antwi-Boasiako et al. 2010 Huang et al. 2009

CIRAD 2012 Kilic and Niemz 2012

Saha et al. 2013 CIRAD 2012 C.T.F.T (1976)

Saha et al. 2013 CIRAD 2012

CIRAD 2012 Huang et al. 2009

Kilic and Niemz 2012 CIRAD 2012

CIRAD 2012

Saha et al. 2013 CIRAD 2012

Saha et al. 2013 CIRAD 2012 
Table 1 (continued)

\begin{tabular}{ll}
\hline Wood species & References \\
\hline & $\begin{array}{l}\text { The extract from wood showed the highest } \\
\text { antioxidant activity compared at the }(+) \text {-catechin } \\
\text { compound }\end{array}$ \\
\hline
\end{tabular}

\subsection{Extraction}

Prior to extraction, sawdust was oven dried at $70{ }^{\circ} \mathrm{C}$ until constant mass. Approximatively, 10-15 g of sawdust was then successively extracted with $150 \mathrm{~mL}$ of toluene-ethanol (2/1 $v / v$ ) followed by $150 \mathrm{~mL}$ of ethanol in a Soxhlet extractor. The temperature used to dry sawdust did not degrade extractives molecules and did not influence the yield of extractives (Sirmah et al. 2008). The temperature was regulated so as to have approximately 12 siphons per hour. Extraction was carried out for at least $14 \mathrm{~h}$ to ensure that all extractives soluble in these solvents were effectively removed (until a colorless siphon was obtained). After the extraction, the solvent was evaporated under reduced pressure and the crude extract was dried under vacuum in a desiccator over $\mathrm{P}_{2} \mathrm{O}_{5}$ and then weighed (Neya et al. 2004; Mburu et al. 2007). The amount of extractives was calculated as a percentage of the oven-dried mass of sawdust. All tests were carried four times.

\subsection{Phytochemical screening}

\subsubsection{Chemicals}

Technical-grade ethanol (purity $>95 \%$ ), methanol (purity $>95 \%$ ), citrate buffer, and toluene (purity $>95 \%$ ) were obtained from Carlo Erba; sulfuric acid (purity $>95 \%$ ); FolinCiocalteu reagent, gallic acid, sodium carbonate, hydrogen peroxide, peroxidase, agar powder, and malt extract were obtained from Acros Organics (Fisher Scientific SAS, Strasbourg, France); and ABTS (acid, 2, 2-azino-bis (3-ethylbenzothiazoline)-6-sulfonic acid), ferric chloride, ascorbic acid were purchased from Sigma-Aldrich SARL (Saint Quentin Fallavier, France); water and acetone were distilled before use. Mayer's reagent (potassium mercuric iodide solution), Bouchardat reagent $(2 \%$ iodine in a $4 \%$ solution of potassium iodide) and Shinoda reagent (magnesium hydrochloride reduction) were prepared in laboratory from reagent-grade chemicals.

\subsubsection{Identification of chemical families}

Different phytochemical screening reagents were prepared and used according the conventional procedures described in literature (Vigor et al. 2009; Akinjogunla et al. 2010). Ferric chloride (10\%) was used for the detection of tannins; Mayer's and Bouchardat reagents for the detection of alkaloids; Shinoda reagent for the detection of flavonoids and Liebermann-Buchard reagent for the detection of sterols and terpenes. Frothing test was used for the detection of saponins (Uddin et al. 2011). These are usual tests in phytochemistry and pharmacology.

\subsection{Determination of lignin content}

Extracted sawdust was oven dried at $103{ }^{\circ} \mathrm{C}$ for $24 \mathrm{~h}$ before acid hydrolysis. Three-hundred fifty milligrams of sawdust was placed in a flask and $3 \mathrm{~mL}$ of $72 \%$ sulfuric acid added. The mixture was gently stirred using a magnetic bar at room temperature for $1 \mathrm{~h}$. After this pre-hydrolysis stage, the medium was diluted by adding $84 \mathrm{~mL}$ of distilled water. An oil bath was then used to heat the reaction mixture to boiling, and the reaction was maintained under reflux for $4 \mathrm{~h}$. At the end of the hydrolysis, the flask was cooled to room temperature and the content of the flask filtered with Whatman paper no. 1 on a Büchner. Lignin retained on the paper was rinsed with $100 \mathrm{~mL}$ of distilled water and then dried in an oven at $103{ }^{\circ} \mathrm{C}$ for $48 \mathrm{~h}$ and weighed $\left(m_{1}\right)$. All tests were done four times. The percentage of Klason lignin is given by Formula (1).

Klason lignin $(\%)=\frac{m_{1}}{350} \times 100$

where $m_{1}$ is the oven-dried mass of lignin (mg).

\subsection{Determination of total phenolic content in the extracts}

Total phenolic content (TPC) of the different extracts were quantified using the Folin-Ciocalteu method with a slight modification (Diouf et al. 2006; Huang et al. 2009). Each extract was diluted in methanol to obtain a final absorbance comprised between 0 and 0.5 . A $2.5 \mathrm{~mL}$ portion of FolinCiocalteu reagent (diluted ten times in methanol) and $2 \mathrm{~mL}$ of an aqueous sodium carbonate solution $(75 \mathrm{~g} / \mathrm{L})$ were added to $0.5 \mathrm{~mL}$ of the methanolic solution of the extract. Sodium carbonate is added $30 \mathrm{~s}$ to $8 \mathrm{~min}$ after the Folin-Ciocalteu reagent. The mixture was kept for $5 \mathrm{~min}$ in a water bath at $50{ }^{\circ} \mathrm{C}$ and then transferred to a cold water bath. The mixture was centrifuged and then the absorbance of the supernatant liquid was determined at $760 \mathrm{~nm}$ using a Lambda 16 PerkinElmer UV spectrophotometer. The total phenolic content was calculated as gallic acid equivalent from the calibration curve 
of a gallic acid standard solution $(0-25 \mathrm{mg} / \mathrm{L})$ and expressed as milligrams of gallic acid equivalent/g of extract. All tests were carried out four times.

\subsection{Determination of antioxidant activity}

The antioxidant activity of each extract was quantified using the ABTS+ scavenging activity method with a slight modification (Piccolella et al. 2008). ABTS+ was generated by placing $100 \mu \mathrm{L}$ of ABTS in contact with $20 \mu \mathrm{L}$ of peroxidase (950-2000 units/mg solid ABTS) and $100 \mu \mathrm{L} \mathrm{H}_{2} \mathrm{O}_{2}$ in $5 \mathrm{~mL}$ of citrate buffer $(100 \mathrm{mM}, \mathrm{pH}=5)$. The mixture was introduced into a $15-\mathrm{mL}$ Erlenmeyer flask and allowed to stand for $1 \mathrm{~h}$. It was then heated at $95{ }^{\circ} \mathrm{C}$ for $30 \mathrm{~min}$ and kept between 0 and $5{ }^{\circ} \mathrm{C}$ in a refrigerator overnight before use. To measure antioxidant capacity, $970 \mu \mathrm{L}$ of buffer were mixed with $30 \mu \mathrm{L}$ of prepared solution (containing ABTS, peroxidase, buffer solution, and hydrogen peroxide) and $1 \mu \mathrm{L}$ of a $10 \mathrm{mg} / \mathrm{L}$ extract solution in methanol. After $20 \mathrm{~min}$ of incubation, absorbance was measured at $735 \mathrm{~nm}$ using a VARIAN CARY 50 UV-Visible spectrophotometer. The antioxidant capacity was calculated as ascorbic acid equivalent from the calibration curve of an ascorbic acid standard solution (0$0.7 \mu \mathrm{g} / \mathrm{mL}$ ) and expressed as micromoles of ascorbic acid per micrograms of dry extract. All tests were carried out four times.

\subsection{Micro-organisms}

The fungal strains of $P$. sanguineus MUCL 51321 and P. chrysosporium MARD78 used in this work were obtained, respectively, from the Mycothèque of Catholic University of Louvain in Belgium and the Interactions Arbres Microorganismes laboratory of the University of Lorraine in France. Cultures were maintained on malt-agar media whose $\mathrm{pH}$ was adjusted to 4.8 and comprising $40 \mathrm{~g} / \mathrm{L}$ of malt and $30 \mathrm{~g} / \mathrm{L}$ of agar. The cultures were grown at $22{ }^{\circ} \mathrm{C}$ and $70 \%$ relative humidity during 1 week.

\subsection{Decay tests on sawdust in laboratory}

The test to evaluate the resistance of wood to fungal colonization was carried out on sawdust according to the method described by Oliveira et al. (2010) with a slight modification using two white rot fungi, a tropical fungus $P$. sanguineus and a temperate fungus $P$. chrysosporium. In this visual monitoring, the extent (or size) of the mycelium on sawdust was evaluated. About $2.50 \mathrm{~g}$ of extracted or unextracted sawdust (particle size $>0.4 \mathrm{~mm}$ ) were weighed in a $200-\mathrm{mL}$ Erlenmeyer flask. The flask was closed with cotton wool and then autoclaved at $120{ }^{\circ} \mathrm{C}$ for $20 \mathrm{~min}$. The flask was allowed to cool under sterile conditions in a flow hood and then humidified with $1 \mathrm{~mL}$ of distilled water. Two 5-mm diameter disks from a solid culture medium inoculated with the fungus were added in each flask. The flasks were then closed and maintained at $22{ }^{\circ} \mathrm{C}$ and $70 \%$ of relative humidity; fungal growth was evaluated after 4 weeks. Non-inoculated sterilized sawdusts of the different tree species were used as control. Poplar heartwood sawdust was used as the positive control. All tests were carried out in triplicates.

\section{Results}

After quantification of extractive contents and phytochemical screening of the main compounds present in these latter ones, effect of extractives was investigated on fungal colonization and antioxidant properties.

\subsection{Decay resistance}

Table 2 presents the effect of extractives on wood sawdust fungal colonization. Compared to the positive control (poplar), none of the two tested fungi grows on Bilinga sawdust which was either extracted or not, corroborating its high decay resistance (Antwi-Boasiako et al. 2010). On the other hand, P. sanguineus was able to rapidly colonize the sawdust of Bahia and Ozigo, indicating lower resistance of these two tree species to this fungus. The resistance of tali, okan, and doussie is relatively good against $P$. sanguineus even after solvent extraction, while moabi, movingui, and padouk seem moderately resistant or more easily colonized after removal of extractives by $P$. sanguineus, indicating the implication of these latter ones in natural durability. In addition, the growth of $P$. chrysosporium on extracted sawdust of moabi, movingui, and padouk or on poplar sawdust (extracted or not) remains very low compared to that of $P$. sanguineus, showing the lower colonization rate of this fungus strain.

\subsection{Extractives content}

The extractive contents of heartwood using toluene/ ethanol mixture in a first extraction followed by ethanol in a second extraction are presented in Table 3 . The extractive content depends on the nature of the tree species. The overall extractive contents varied considerably depending on the trees species. Lower contents were observed with Bahia containing only $2.7 \%$ of extractives, while higher contents were obtained for okan with $16 \%$ of extractives. Other tree species presented intermediate contents between the two previous species.

In all cases, tree species which contained low amounts of extractives (Bahia, Okoume, and Ozigo) seemed to be more 
Table 2 Effect of extractives on wood sawdust fungal colonization

\begin{tabular}{|c|c|c|c|c|c|c|c|c|c|c|c|c|}
\hline & Wood sawdust & Bahia & Bilinga & Doussie & Moabi & Movingui & Okan & Okoume & Ozigo & Padouk & Tali & Poplar \\
\hline \multirow[t]{2}{*}{ Pycnoporus sanguineus } & Unextracted & +++ & - & + & + & + & + & nd & ++ & + & - & +++ \\
\hline & Extracted & +++ & - & + & ++ & +++ & + & nd & ++ & +++ & + & +++ \\
\hline \multirow[t]{2}{*}{ Phanerochaete chrysosporium } & Unextracted & nd & - & - & + & - & - & + & + & + & nd & ++ \\
\hline & Extracted & nd & - & + & + & + & - & ++ & ++ & + & nd & ++ \\
\hline
\end{tabular}

The parameter that is evaluated visually is the colonized surface. All tests are conducted thrice

$n d$ test not done (lack of sufficient quantities of sawdust), +++ Important growth of fungus, ++ moderate growth of fungus, + poor growth of fungus, - no growth

susceptible to fungal colonization than tree species containing higher amounts of extractives. Sawdust of tree species, such as movingui, moabi, padouk, presented a greater susceptibility to colonization by $P$. sanguineus after extraction, clearly indicating that the amount and the nature of extractives affect the natural resistance of these species. However, since the most durable tree species of this study is Bilinga which is far from being the extractives' richest sample, it was difficult to conclude definitively about a positive correlation between decay resistance and such a basic value as the overall extractives content.

\subsection{Klason lignin content}

Heartwood Klason lignin contents are shown in Table 3. The average lignin contents vary from 26.5 to $35.9 \%$. Two wood samples, Bahia and movingui, had relatively low lignin contents of 26.5 and $25.7 \%$. Lignin contents in the range of 28.4 $29.30 \%$ were observed for Okoume, Ozigo, padouk, and moabi. The remaining wood samples, Bilinga, doussie, okan, and tali, were observed to have relatively high lignin contents of $31.2-35.9 \%$.

\subsection{TPC}

The total phenolic contents of extractives in the two solvents measured by the Folin-Ciocalteu method are shown in Table 4. They varied between 51 and 935 eq. gallic acid/g of extract. The highest value obtained was $935 \mathrm{mg}$ eq. gallic acid/g of extract for the toluene-ethanol extract of doussie while the lowest was $51 \mathrm{mg}$ eq. gallic acid/g of ethanol extract of moabi.

\subsection{Antioxidant properties of extractives}

The antioxidant activities given in Table 3 vary from 18 to $175 \mu \mathrm{mol} \mathrm{AAE} / \mu \mathrm{g}$ of extract. The highest antioxidant activity was that of doussie $(175 \mu \mathrm{mol} \mathrm{AAE} / \mu \mathrm{g}$ of extract $)$ with toluene-ethanol as solvent and the lowest was that of Bahia (18 $\mu \mathrm{mol} \mathrm{AAE} / \mu \mathrm{g}$ of extract) with ethanol as solvent. Among

Table 3 Lignin content, extractives contents, and their corresponding total phenolic content (TPC) and antioxidant activity (AA) of the different studied wood species

\begin{tabular}{|c|c|c|c|c|c|c|c|c|c|c|}
\hline & Bahia & Bilinga & Doussie & Moabi & Movingui & Okan & Okoume & Ozigo & Padouk & Tali \\
\hline${ }^{\mathrm{a}}$ Toluene/ethanol extract $(\%)$ & $2.2 \pm 0.5$ & $5.8 \pm 1.0$ & $10.8 \pm 1.0$ & $7.8 \pm 0.2$ & $8.7 \pm 0.1$ & $11.4 \pm 2.0$ & $2.8 \pm 0.5$ & $2.1 \pm 0.3$ & $7.8 \pm 0.3$ & $8.5 \pm 0.4$ \\
\hline${ }^{\mathrm{b}} \mathrm{TPC}$ & 119 & 164 & 935 & 54 & 490 & 829 & 122 & 146 & 273 & 581 \\
\hline${ }^{\mathrm{c}} \mathrm{AA}$ & 20 & 22 & 175 & 48 & 54 & 133 & 23 & 23 & 32 & 118 \\
\hline${ }^{\mathrm{a}}$ Ethanol extract $(\%)$ & $0.4 \pm 0.1$ & $1.6 \pm 0.1$ & $2.0 \pm 0.5$ & $2.2 \pm 0.2$ & $3.0 \pm 0.3$ & $4.1 \pm 1.2$ & $0.5 \pm 0.2$ & $1.1 \pm 0.4$ & $2.0 \pm 0.1$ & $3.8 \pm 2.0$ \\
\hline${ }^{\mathrm{b}} \mathrm{TPC}$ & 268 & 239 & 582 & 51 & 359 & 559 & 105 & 298 & 172 & 450 \\
\hline${ }^{\mathrm{c}} \mathrm{AA}$ & 18 & 20 & 140 & 32 & 36 & 114 & 26 & 27 & 31 & 96 \\
\hline${ }^{\mathrm{a}}$ Total extractive content $(\%)$ & $2.7 \pm 0.6$ & $7.7 \pm 1.2$ & $13.5 \pm 1.3$ & $10.0 \pm 0.4$ & $11.7 \pm 0.5$ & $16.0 \pm 2.0$ & $3.5 \pm 0.7$ & $3.3 \pm 0.7$ & $9.8 \pm 0.4$ & $12.3 \pm 2.0$ \\
\hline${ }^{\mathrm{d}}$ Lignin content $(\%)$ & $26.5 \pm 1.5$ & $31.2 \pm 1.0$ & $32.2 \pm 1.6$ & $29.3 \pm 1.2$ & $25.7 \pm 1.6$ & $34.4 \pm 1.3$ & $28.4 \pm 1.0$ & $28.3 \pm 1.3$ & $28,9 \pm 1.2$ & $35.9 \pm 0.9$ \\
\hline
\end{tabular}

Average values and SD were obtained on four replicates

${ }^{a}$ The amount of extractives was calculated as a percentage of the initial anhydrous mass of sawdust

${ }^{\mathrm{b}}$ TPC values are in mg eq. gallic acid/g of extract; SD are inferior to 0.01 for all values

${ }^{\mathrm{c}} \mathrm{AA}$ values are in micromoles AAE/ $\mu \mathrm{g}$ of extract; SD are inferior to 0.001 for all values

${ }^{\mathrm{d}}$ Percent of lignin content for each sawdust wood species using standard method 
the ten samples analyzed, three showed important antioxidant activity superior to $96 \mu \mathrm{mol} \mathrm{AAE} / \mu \mathrm{g}$ of extract (doussie, okan, tali); three showed moderate antioxidant activity (moabi, miovingui, padouk with values comprised between 54 and $31 \mu \mathrm{mol} \mathrm{AAE} / \mu \mathrm{g}$ of extract); and four showed low antioxidant activity (values below $28 \mu \mathrm{mol} \mathrm{AAE} / \mu \mathrm{g}$ of extract for Bahia, Bilinga, Okoume, Ozigo). Relative standard deviation was estimated to less than $5 \%$.

\subsection{Chemical screening of extractives}

The results of preliminary screening of extracts for chemical type using phytochemical methods are presented in Table 4. The extracts of all tree species gave positive results with the Shinoda test, ferric chloride tests, and Liebermann-Buchard tests indicating the presence of tannins, flavonoids, steroids, and terpenes. Tannins and flavonoids are present in high amounts in seven tree species, respectively, but in low quantities in the three others (Bahia, Okoume, Ozigo). The MayerBouchardard test was positive only for tali indicating the possible presence of alkaloids. Saponins were detected in variable proportions in tali, moabi, Bilinga, okan, and Bahia extractives but were completely absent in all the other wood extracts.

\section{Discussion}

\subsection{Decay resistance}

At first observation, wood colonization by $P$. chrysosporium appears slower than that observed with $P$. sanguineus. However, it has to be noted that, despite this low rate of colonization, $P$. chrysosporium had moderate growth on the extracted sawdust of Ozigo, Okoume, and all poplar sawdusts (positive control). For all the other unextracted sawdusts, this fungus showed poor or no growth.

In the case of $P$. sanguineus, all unextracted sawdusts of tropical woods investigated in our study slowed down the growth of fungus, except for Bahia and Ozigo which have been reported to possess very low natural decay resistance against fungal attack (CIRAD 2012). It is therefore clear that extractives contribute to natural durability of these African tropical woods, confirming earlier studies on the natural durability of African tropical woods (Gérardin et al. 2004; Neya et al. 2004; Mburu et al. 2007; Antwi-Boasiako and Pitman 2009; Antwi-Boasiako et al. 2010).

\subsection{Extractive contents}

The overall extractive contents vary considerably with the tree species, as expected. Results obtained by Huang et al. (2009), Kilic and Niemz (2012), Ndukwe et al. (2012), and Saha et al. (2013) show that there is a great variability in the quantity of extractives in African tropical tree species. The extractive contents of Okoume, Ozigo, and Bahia were approximately $83 \%$ smaller than those of okan. Prior studies on Okoume showed extractive content of $2.3 \%$ (Fengel and Wegener 1989) and $3.15 \%$ (Kilic and Niemz 2012) which are comparable to the $3.5 \%$ obtained in our study. Extractives content of okan are also similar to those obtained by Huang et al. (2009). In all cases, tree species containing low amounts of extractives $(\mathrm{Ba}-$ hia, Okoume, and Ozigo) seem to be more susceptible to fungal colonization than tree species containing higher amounts of extractives. Bilinga and okan, which are both only slightly colonized or not at all, had different amounts of extractives ( $7.7 \%$ for Bilinga compared to $16 \%$ for okan). The differences in nature and quantity of extractives probably explain the different behaviors of these tree species (Neya et al. 2004; Nascimento et al. 2013). In addition, other authors have shown that extractives may have different levels of antifungal or antioxidant properties, possibly explaining the differences in fungal resistance observed above (Amusant et al. 2007; Mburu et al. 2007; Huang et al. 2009; Saha et al. 2013).

\subsection{Lignin content}

The results obtained in this study are similar with those described in the literature with lignin contents of $30.55 \%$ for padouk, $32 \%$ for tali, $30.55 \%$ for moabi, $29.07 \%$ for Bilinga,

Table 4 Preliminary phytochemical analysis of the main groups in extractives woods

\begin{tabular}{|c|c|c|c|c|c|c|c|c|c|c|c|}
\hline Active compounds & Test procedure & Bahia & Bilinga & Doussie & Moabi & Movingui & Okan & Okoume & Ozigo & Padouk & Tali \\
\hline Sterols and terpenes & Liebermann-Buchard & + & ++ & + & +++ & +++ & + & +++ & ++ & ++ & ++ \\
\hline Alkaloids & Mayer, Bouchardat & - & - & - & - & - & - & - & - & - & + \\
\hline Saponins & Flotting & + & + & - & +++ & - & ++ & - & - & - & + \\
\hline Tannins & Ferric chloride & + & +++ & +++ & ++ & +++ & +++ & + & + & +++ & +++ \\
\hline Flavonoids & Shinoda test & + & ++ & +++ & ++ & +++ & +++ & ++ & + & +++ & +++ \\
\hline
\end{tabular}

The popular colorimetric methods for identify chemicals groups on plant parts. All tests are replicated four times

+++ Present in high concentration, ++ present in moderate concentration, + present in low concentration, - not detected 
and $31.4 \%$ for $31.4 \%$ for Okoume (CTFT 1976; Fengel and Wegener 1989; Ndukwe et al. 2012). Some authors have claimed that lignin quantity and type may contribute to the susceptibility of the heartwood to attack and deterioration by different fungi (Tuomela et al. 2000; Oliveira et al. 2010; Skyba et al. 2013), but these claims remain controversial. In our study on unextracted and extracted sawdust of Bilinga, no fungi growth was observed. Tree species like tali, Bilinga, okan, and doussie have both high lignin contents and higher resistance to fungal colonization and probably to subsequent degradation. These results suggest that lignin could have an effect on the natural resistance of wood in some species.

\subsection{TPC}

Moabi had the lowest phenolic content and doussie the highest. In a similar study on 22 varieties of tropical tree species, Huang et al. (2009) obtained similar results with a high variability of phenolic contents within species. Others studies (Aloui et al. 2004; Niamké et al. 2011) have shown that the presence of phenolic compounds is positively correlated with natural durability.

\subsection{Antioxidant properties of extractives}

Antioxidant activities of ethanolic extracts were generally lower than those of toluene-ethanol, probably due to the removal of most polar phenolic antioxidant compounds during the first extraction. Antioxidant activity can be directly linked to the amount of phenolic compounds as demonstrated by higher antioxidant properties measured for okan, doussie, and tali. Nevertheless, moabi, which had a lower phenolic content, presented an antioxidant activity approximately two times higher than Bilinga and Bahia which had much higher phenolic contents. These differences can probably be explained by the nature of phenolic compounds (Saha et al. 2013). The results obtained are consistent with the data reported by Huang et al. (2009), even if different antioxidant test systems were used.

\subsection{Chemical screening of extractives}

Some phytochemical screening results obtained in our study are consistent with those obtained in literature for Bilinga, Okoume, tali, and padouk using GC-MS analysis (Kilic and Niemz 2012; Saha et al. 2013). Most of the tree species studied present significant amounts of phenolic extractives such as tannins and flavonoids as demonstrated by the positive response to ferric chloride and Shinoda tests. Phenolic compounds have been reported in the literature to possess antioxidant, antibacterial, and antifungal activity which may be responsible of the natural durability of the corresponding tree species (Amusant et al. 2007). The presence of sterols and/or terpenes was systematic on all woods in our study. In addition, these compounds have been observed on different tropical woods (Mburu et al. 2007; Kilic and Niemz 2012). Alkaloids were very rarely present on wood; tali being the sole tree species responding positively to the Mayer Bouchardat test. Alkaloids have also been reported to present antifungal, antibacterial, and antimicrobial activities on woods (Onuorah 2000; Wu and Lin 2001; Oliveira et al. 2010). According to literature, most groups of compounds identified could contribute to the natural resistance of corresponding tree species (Amusant et al. 2007; Mburu et al. 2007). The influence of extractives is particularly obvious for the padouk and movingui samples containing high amounts of phenolic extractives constituted of tannins and flavonoids. Indeed, $P$. sanguineus developed easily on the extracted sawdust of these two species, while no mycelium growth was observed on unextracted sawdust.

\subsection{Relations between extractives content, antioxidant activity, and fungal durability}

Antioxidant activity generally increased with the total phenolic content in the extracts. It was found that tali, okan, doussie, and movingui had high phenolic contents (tannins and flavonoids) contributing to the antioxidant activity of these species. Diouf et al. (2006) and Huang et al. (2009) had shown that the total phenolic content was related to the antioxidant activity. In fact, a correlation coefficient of 0.92 between antioxidant activity and total phenolic content was obtained by Diouf et al. (2006).

It seems that there is only a moderate correlation between antioxidant activity and extractive content, probably because of the presence of other families of extractives with no antioxidant activity. Moabi, for example, had high extractives contents of about $10 \%$ but a low antioxidant capacity (32 $\mu \mathrm{mol} \mathrm{AAE} / \mu \mathrm{g}$ of extract in ethanol solvent); this could be explained by its low phenolic content compared to other tree species. Huang et al. (2009) obtained similar results with Lophira alata which had $1.69 \%$ of extractives with higher antioxidant capacity than Terminalia ivorensis which had $18.21 \%$ of extractives. However, for the tree species studied, the general trend is that extractives contents evolved in the same direction as antioxidant activity.

According to literature, good correlations exist between wood extractives content and natural durability versus rotting fungi (Aloui et al. 2004; Guilley et al. 2004; Antwi-Boasiako et al. 2010). Independent of the phytochemical nature of extractives, the amount of extractives in the tree species directly influences the colonization of wood by the different fungal species and consequently its potential natural durability.

However, if high values of extractives content, antioxydant activity, and TPC allow to expect a good decay resistance, the opposite is not true. Bilingua is a very typical example of this 
reality since it is the most durable tree species of this study but comprising a moderate overall extractives content, one of the weakest antioxidant activity and relatively low TPCs particularly for toluene/ethanol extracts. These characteristics are even not counterbalanced by its average lignin content. This case suggests that a more careful and precise identification of the chemicals is necessary for completely understanding the origin of the natural durability against fungi and expect to use it to develop modern preservation cocktails.

\section{Conclusion}

The development of mycelium was generally strongly dependent on the presence of extractives: tree species with high extractive contents were poorly colonized by the two fungal strains used in this study. Conversely, tree species with low extractive content such as Bahia, Okoume, and Ozigo were easily colonized by fungi. It seems that a threshold value for the Klason lignin content was a promising clue for the decay resistance. Antioxidant properties were directly related to phenolic content even if the nature of phenolic compounds may led to more or less antioxidant activity and, by this way, an evidence for decay resistance. Phytochemical screening highlighted the presence of different chemical groups in the extractives of tropical tree species studied. The presence of tannins and flavonoids was detected in variable quantities in different tree species. Saponins were detected only in some species like tali, okan, Bilinga, and moabi, while alkaloids were present only in tali. In front of this variety of chemicals types, further studies are however necessary to identify the exact nature of chemical compounds present in these extracts and understand their precise role in the fungal resistance of tree species. Nevertheless, it is clear that tree species with high amounts of extractives and mainly tannins and flavonoids were more resistant than other woods.

\begin{abstract}
Acknowledgments This article is dedicated to the memory of Professor Joseph Noah Ngamveng who died in August 2012. The authors gratefully acknowledge the financial support of the International Tropical Timber Organization (ITTO) Fellowship Program for the award granted to Dr Mounguengui to conduct analyses at LERMAB (France) and of CPER 2007-2013 "Structuration du Pôle de CompétitivitéFibresGrand'Est" (Competitiveness Fibers Cluster). LERMaB is supported by the French National Research Agency through the Laboratory of Excellence ARBRE (ANR-12-LABXARBRE-01).
\end{abstract}

\section{References}

Akinjogunla OJ, Yah CS, Eghafona NO, Ogbemudia FO (2010) Antibacterial activity of leave extracts of Nymphaea lotus (Nymphaeaceae) on methicillin resistant Staphylococcus aureus (MRSA) and vancomycin resistant Staphylococcus aureus (VRSA) isolated from clinical samples. Ann Biol Res 1:174-184
Aloui F, Ayadi N, Charrier F, Charrier B (2004) Durability of European oak (Quercus petraea and Quercus robur) against white rot fungi (Coriolus versicolor): relations with phenol extractives. Holz Roh Werkst 62:286-290

Amusant N, Moretti C, Richard B, Prost E, Nuzillard M, Thevenon MF (2007) Chemical compounds from Eperuafalcata and Eperua grandiflora heartwood and their biological activities against wood destroying fungus (Coriolusversicolor). Holz Roh Werkst 65:23-28

Antwi-Boasiako C, Pitman AJ (2009) Influence of density on the durabilities of three Ghanaian timbers. J Sci Technol 29:34-45

Antwi-Boasiako C, Barnett JR, Pitman AJ (2010) Relationship between total extractive content and durability of three tropical hardwoods exposed to Coriolus versicolor (Linnaeus) Quelet. J Indian Acad Wood Sci 7:9-13

Centre Technique Forestier Tropical (C.T.F.T) (1976) Moabi. BFT169: $37-49$

COMIFAC Les forêts du bassin du Congo - Etat des Forêts (2010) de Wasseige C, de Marcken P, Bayol N, HiolHiol F, Mayaux Ph, Desclée B, Nasi R, Billand A, Defourny P and Eba'a R 2012 (Eds) Office des publications de l'Union Européenne. Luxembourg. doi:10.2788/48830 276 p. ISBN : 978-92-79-22717-2

Diouf P, Merlin A, Perrin D (2006) Antioxidant properties of wood extracts and color stability of woods. Ann For Sci 63:525-534

Fengel D, Wegener G (1989) Wood chemistry, ultrastructure, reactions. Walter de Gruyter (ed) Berlin, Germany, 600p

Gérardin P, Neya B, Dumarcay S, Petrissans M, Serraj M, Huber F (2004) Contribution of gums to natural durability of Prosopis africana heartwood. Holzforschung 58:39-44

Guilley E, Charpentier JP, Ayadi N, Snakkers G, Nepveu G, Charrier B (2004) Decay resistance against Coriolus versicolor in Sessile oak (Quercuspetraea Liebl.): analysis of the between-tree variability and correlations with extractives, tree growth and other basic wood properties. Wood Sci Technol 38:539-554

Huang Z, Hashadi K, Makino R, Kawamura F, Kuniyoshi S, Ryuichiro K, Ohara $S$ (2009) Evaluation of biological activities of extracts from 22 African tropical wood species. J Wood Sci 55:225-229

Kilic A, Niemz P (2012) Extractives in some tropical woods. Eur J Wood Prod 70:79-83

Kirker GT, Blodgett AB, Arango RA, Lebow PK, Clausen CA (2013) The role of extractives in naturally durable wood species. Int Biodeterior Biodegrad 82:53-58

Kokutse AD, Stokes A, Bailleres H, Kokou K, Baudasse C (2006) Decay resistance of Togolese teak (Tectona grandis L.f) heartwood and relationship with colour. Trees 20:219-223

Mburu F, Dumarçay S, Gérardin P (2007) Evidence of fungicidal and termicidal properties of Pronus africana heartwood extractives. Holzforschung 61:323-325

Nascimento MS, Santana ALBD, Maranhão CA, Oliveira LS, Bieber L (2013) Chapter 13 phenolic extractives and natural resistance of wood. In: Chamy R and Rosenkranz F (eds) Biodegradation-life of science. InTech, p 349-370. doi:10.5772/56358

Ndukwe NA, Okiei WO, Alo BI (2012) Correlates of the yield of chemical pulp, lignin and the extractive materials of tropical hardwoods. Afr J Agric Res 7:5518-5524

Neya B, Hakkou M, Petrissans M, Gerardin P (2004) On the durability of Burkea africana heartwood: evidence of biocidal and hydrophobic agents responsible for durability. Ann For Sci 61:277-282

Niamké BF, Amusant N, Charpentier J-P, Chaix G, Baissac Y, Boutahar N, Adima AA, Kati-Coulibaly S, Jay-Allemand C (2011) Relationships between biochemical attributes (non-structural carbohydrates and phenolics) and natural durability against fungi in dry teak wood (Tectona grandis L. f.). Ann For Sci 68:201-211

Niamké BF, Amusant N, Stien D, Chaix G, Lozano Y, Kadio AA, Lemenager N, Goh D, Adima AA, Kati-coulibaly S, Jay-allemand C (2012) Dihydroxy-epiisocatalponol, a new naphthoquinone from 
Tectona grandis L.f. heartwood and fungicidal activity. Int Biodeterior Biodegrad 74:93-98

Nzokou P, Wehner K, Kamdem DP (2005) Natural durability of eight tropical hardwoods from Cameroon. J Trop For Sci 17:416-427

Oliveira LS, Santana LBDA, Maranhão AC, de CR M d M, de GVLA L, da IS S, Nascimento SM, Bieber L (2010) Natural resistance of five woods to Phanerochaete chrysosporium degradation. Int Biodeterior Biodegrad 64:711-715

Onuorah EO (2000) The wood preservative potentials of heartwood extracts of Milicia excelsa and Erythrophleum suaveolens. Bioresour Technol 75:171-173

Pettersen RC (1984). The chemical composition of wood. In: Rowell, RM (ed) The chemistry of solid wood. Advances in chemistry series 207, vol. 207. American Chemical Society; chapter 2, The chemistry of solid wood. Washington, DC, pp 57-126

Piccolella S, Fiorentino A, Pacifico S, D'Abrosca B, Uzzo P, Monaco P (2008) Antioxidant properties of sour cherries (Prunus cerasusL.): role of colorless phytochemicals from the methanolic extract of ripe fruits. J Agric Food Chem 56:1928-1935

Saha TJB, Abia D, Dumarçay S, Ndikontar KM, Gérardin P, Noah NJ, Perrin D (2013) Antioxidant activities, total phenolic contents and chemical compositions of extracts from four Cameroonian woods: padouk (Pterocarpus soyauxii Taubb), tali (Erythrophleum suaveolens), moabi (Baillonella toxisperma), and movingui (Distemonanthus benthamianus). Ind Crop Prod 41:71-77

Schultz TP, Nicholas DD (2002) Naturally durable heartwood: evidence for a proposed dual defensive function of the extractives. Phytochemistry 54:47-52

Sirmah P, Muisu F, Mburu F, Dumarçay S, Gérardin P (2008) Evaluation of Prosopis juliflora properties as an alternative to wood shortage in Kenya. Bois et forêts des tropiques 298:25-35

Skyba O, Douglas CJ, Mansfield SD (2013) Syringyl-rich lignin renders poplars more resistant to degradation by wood decay fungi. Appl Environ Microbiol 79:2560-2571

Tropix 7, CIRAD 2012 (http://tropix.cirad.fr) consulted 24/04/2015

Tuomela M, Vikman, Hatakka A, Itavaara M (2000) Biodegradation of lignin in a compost environment: a review. Bioresour Technol 72: 169-183

Uddin G, Rauf A, Siddiqui SB, Shah QS (2011) Preliminary comparative phytochemical screening of Diospyros lotus Stewart. Middle-East J Sci Res 10:78-81

Vigor C, Vercauteren J, Montels J (2009) Les substances naturelles dans « la chaîne du médicament ", première partie initiation à la pharmacognosie.Université de Montpellier I, $49 \mathrm{p}$

Wu TS, Lin FW (2001) Alkaloids of the wood of Cryptocarya chinensis. J Nat Prod 64:1404-1407 